DOI: $10.17951 / 1 r p .2020 .39 .1 .149-164$

\author{
Alicja LisieCKa \\ Uniwersytet Marii Curie-Skłodowskiej w Lublinie \\ Wydział Pedagogiki i Psychologii \\ ORCID - 0000-0003-0080-6314
}

\title{
PROBLEMATYKA POWSZECHNEGO NAUCZANIA ROBÓT RĘCZNYCH NA ŁAMACH KWARTALNIKA „PRACA RĘCZNA W SZKOLE” (1927-1939)
}

\begin{abstract}
Streszczenie: W latach międzywojennych polska prasa pedagogiczna przeżywała intensywny rozwój. Ukazywały się liczne periodyki poświęcone problematyce szkolnictwa powszechnego, średniego i zawodowego, czasopisma traktujące o oświacie pozaszkolnej oraz pisma metodyczno-przedmiotowe. Jednym z uznanych pism metodycznych była „Praca Ręczna w Szkole” (1927-1939). Na łamach kwartalnika podejmowano szeroko rozumianą problematykę nauczania robót ręcznych w szkołach ogólnokształcących: omawiano zagadnienie wpływu pracy ręcznej na rozwój ucznia, przedstawiano rozwiązania metodyczne zarówno w ujęciu teoretycznym, jak i praktycznym oraz wskazywano na związki przedmiotu z wychowaniem estetycznym i innymi zajęciami nauczanymi w szkołach. Liczne numery zawierały sprawozdania ze zjazdów, wystaw czy konferencji odbywających się w kraju i za granicą. Kwartalnik prezentował celowo dobrane artykuły wspierające samokształcenie nauczycieli. Stałe grono specjalistów w swoich opracowaniach poruszało szeroki zakres tematów: od naukowej organizacji procesu nauczania poprzez sztukę aż po motoryzację. Teksty zamieszczane w „Pracy Ręcznej w Szkole” stawały się przyczynkiem do dyskusji i refleksji nad organizacją szkolnictwa.
\end{abstract}

Słowa kluczowe: szkolnictwo powszechne, prace ręczne, polskie czasopisma, XX wiek

\section{WPROWADZENIE}

W latach 1918-1939 w Polsce nastąpił znaczny rozwój prasy, spowodowany przede wszystkim postępem w zakresie technik druku. Rozwój przemysłu poligraficznego przyczynił się do spadku cen periodyków, a w konsekwencji do ich upowszechnienia. Prasa pedagogiczna lat międzywojennych była bardzo zróżnicowana. Szeroką 
grupę stanowiły pisma ogólnopedagogiczne, poświecone problematyce szkół powszechnych, średnich i zawodowych. Ukazywały się również liczne czasopisma traktujące o oświacie pozaszkolnej oraz pisma metodyczno-przedmiotowe. Zdecydowana większość była publikowana w języku polskim, rzadziej w niemieckim, ukraińskim czy litewskim. Bibliografia polskich czasopism pedagogicznych (do 1979 r. $)^{1}$ wymienia ponad czterysta tytułów periodyków pedagogicznych wydawanych w omawianym okresie.

Jednym z uznanych czasopism metodycznych poświęconych robotom ręcznym był kwartalnik „Praca Ręczna w Szkole” (1927-1938). Inicjatorem powstania pisma oraz jego wieloletnim redaktorem był inż. Władysław Przanowski - dyrektor Państwowego Instytutu Robót Ręcznych w Warszawie ${ }^{2}$. Kwartalnik stanowił organ Towarzystwa Miłośników Robót Ręcznych ściśle związanego z Instytutem ${ }^{3}$. Towarzystwo reprezentowało kierunek manualny w polskim szkolnictwie ogólnokształcącym i konsekwentnie dążyło do podniesienia poziomu nauczania robót. Skupiało teoretyków i praktyków przedmiotu, którzy podzielali przekonanie o potrzebie rozwijania wśród odbudowującego się społeczeństwa zamiłowania do pracy fizycznej, a w szczególności o konieczności wszechstronnego wychowania młodzieży, poprzez uwzględnienie w programach szkolnych zajęć rzemieślniczych i przemysłowych ${ }^{4}$.

W skład komitetu redakcyjnego kwartalnika w różnych okresach wchodzili: Zygmunt Andrzejewski, Wacław Radwan, Antoni Wójtów, Wiktoria Dybowska i Hanna Sadowska. Po śmierci Władysława Panowskiego w 1937 roku redakcję czasopisma objął Stanisław Malec. Na łamach „Pracy” wielokrotnie publikowano artykuły autorstwa wykładowców Państwowego Instytutu Robót Ręcznych, m.in. Władysława Przanowskiego, Wincentego Czerwińskiego, Ignacego Hubera,

${ }^{1}$ S. Możdżeń, J. Musiał, 1981, Bibliografia polskich czasopism pedagogicznych (do 1979 r.). Kielce, Wydawnictwo Wyższej Szkoły Pedagogicznej im. Jana Kochanowskiego.

${ }^{2}$ Państwowy Instytut Robót Ręcznych w Warszawie (PIRR) - instytucja kształcenia nauczycieli robót ręcznych dla wszystkich typów placówek oświaty oraz seminariów nauczycielskich. Powstała w 1923 roku na podstawie kursów organizowanych od 1915 roku w Szkole Rzemieślniczej im. Karola Szlenkiera, których założycielem był pierwszy dyrektor Instytutu - Władysław Przanowski. Instytut stanowił centrum metodyczne nauczania robót ręcznych, skupiające teoretyków, praktyków oraz entuzjastów przedmiotu.

3 Towarzystwo Miłośników Robót Ręcznych powstało w 1927 roku, zgodnie z uchwałami I Polskiego Zjazdu Nauczycieli Robót Ręcznych, który odbył się w czerwcu 1928 roku. Towarzystwo działało na podstawie statutu opublikowanego w 1927 roku. Siedzibą była Warszawa i budynek PIRR; w całym kraju funkcjonowały koła Towarzystwa. Pierwszy Zarząd tworzyli: Tadeusz Łopuszański, Maria Zaborowska, Władysław Przanowski, Zygmunt Andrzejewski, Antoni Wójtów, Jadwiga Dziubińska, Edward Geisler, Wacław Hauszyld, Emanuel Łoziński, Antoni Mencel, Władysław Radwan i Józef Wójcik.

${ }^{4}$ W. Ambroziewicz, 1964, Władysław Przanowski i jego dzieło. Warszawa, Państwowe Zakłady Wydawnictw Szkolnych, s. 177. 
Walentego Czyżyckiego, Marii Vogelsang (Soczyńskiej), Stanisława Gabriela, Piotra Tadeusza Pietrzykowskiego i Antoniego Wójtowa. Opublikowane w „Pracy Ręcznej w Szkole” teksty metodyczne stały się podstawą dla wielu podręczników i opracowań zwartych.

W początkowym okresie wydawania kwartalnika artykuły poruszały głównie kwestie praktyczne nauczania robót, w następnych latach zaś charakter pisma ewoluował w kierunku ogólnoteoretycznym. Jak twierdzi Wiktor Ambroziewicz - dyrektor PIRR w latach 1945-1950 - to świadome posunięcie wynikało z ukształtowania się profilu dwóch innych czasopism poświęconych temu samemu przedmiotowi, a mianowicie: czasopisma „Młody Technik” oraz „Roboty Ręczne i Rysunki”. Jak pisze Wiktor Ambroziewicz, „«Młody Technik» podawał młodzieży do rozwiązywania wyraźne praktyczne zagadnienia, a «Roboty Ręczne i Rysunki» były przeznaczone przede wszystkim dla nauczycieli szkół powszechnych uczących przedmiotu, nie posiadających specjalnego fachowego przygotowania. Czasopismo związkowe słusznie wychodziło z założenia podawania czytelnikowi wskazówek praktycznych - co, jak i z czego robić? Obydwa czasopisma w znacznym stopniu odciążały Kwartalnik od tematów zbyt drobiazgowych i pozwoliły zachować kierunek bardziej ogólny, do pewnego stopnia encyklopedyczny"7.

W założeniu wieloletniego redaktora Władysława Przanowskiego kwartalnik miał się stać swojego rodzaju encyklopedią podręczną, z której w razie potrzeby każdy nauczyciel mógł skorzystać, poszukując porad i wskazówek. W poglądach Przanowskiego - którym niejednokrotnie dawał wyraz w tekstach zamieszczanych na łamach „Pracy” - roboty ręczne wykraczały daleko poza wąski obszar slojdu i powielania konkretnych modeli, wchodząc w zakres szeroko rozumianego postępu technicznego i metodycznego. Czasopismo miało umożliwić nauczycielom sprawne podążanie za zachodzącymi w kraju i za granicą przemianami oraz efektywną pracę z myślą o przyszłości całego społeczeństwa.

\footnotetext{
${ }^{5}$ Miesięcznik „Młody Technik” - czasopismo wydawane w Poznaniu przez Leona Rudawskiego od 1932 roku, skierowane do młodzieży szkolnej, poświęcone zajęciom praktycznym, które w założeniu wydawcy „uzupełniało wysiłki władz szkolnych zdążających w kierunku zbliżenia życia szkolnego do praktyczności i zaradności życiowej”. W latach międzywojennych obejmowało następujące działy: a) roboty ręczne: $\mathrm{z}$ kartonu, tektury i z zakresu introligatorstwa, z drzewa, metalu i ze szkła; b) modelarstwo lotnicze; c) radiotechnikę; d) fotografię; e) wynalazki; f) poradnik techniczny i skrzynkę listową. Czasopismo ukazuje się do chwili obecnej.

${ }^{6}$ „Roboty Ręczne i Rysunki” - Organ Sekcji Nauczycieli Robót Ręcznych i Rysunków Związku Polskiego Nauczycielstwa Szkół Powszechnych. Na przestrzeni czasu nazwa czasopisma ulegała następującym zmianom: „Roboty Ręczne” (1927-1928), „Roboty Ręczne i Rysunki” (1929-1933), „Rysunki i Zajęcia Praktyczne” (1933-1934), „Rysunek i Zajęcia Praktyczne” (1934-1939).

7 W. Ambroziewicz, 1964, Władysław Przanowski i jego dzieło. Warszawa, Państwowe Zakłady Wydawnictw Szkolnych, s. 188.
} 
Celem niniejszego tekstu jest przedstawienie zakresu problematyki powszechnego nauczania robót ręcznych podejmowanej na łamach kwartalnika „Praca Ręczna w Szkole” w latach 1927-1939. Czasopismo to w okresie międzywojennym cieszyło się estymą, nadawało kierunek nauczaniu robót w szkołach oraz odgrywało istotną rolę $\mathrm{w}$ procesie samokształcenia nauczycieli, dlatego też tak ważne jest przypomnienie jego znamiennego wkładu w całokształt edukacji powszechnej.

\section{ZAKRES TEMATYCZNY „PRACY RĘCZNEJ W SZKOLE”}

„Praca Ręczna w Szkole” posiadała pewną określoną strukturę, jednak nie zawsze była ona bezwzględnie przestrzegana. Niekiedy numer otwierały komunikaty Towarzystwa Miłośników Robót Ręcznych, sprawozdania ze zjazdów, wystaw lub konferencji ${ }^{8}$. Pismo zawierało stałe rubryki: „Kronikę Instytutu Robót Ręcznych”, „Z terenu pracy nauczycieli zajęć praktycznych” oraz „Przegląd wydawnictw i czasopism”.

Ważną część artykułów stanowiły teoretyczne rozważania nad kwestiami metodycznymi, objaśniające znaczenie i celowość powszechnego kształcenia w zakresie robót ręcznych oraz pożądane sposoby jego realizacji ${ }^{9}$. W tematyce tej na łamach

${ }^{8}$ Np.: Sprawozdanie $z$ Pierwszego Polskiego Zjazdu nauczycieli robót ręcznych $w$ Warszawie, 1927, „Praca Ręczna w Szkole”, nr 1, s. 11-14; Sprawozdanie $z$ wystaw szkolnych, 1927, „Praca Ręczna w Szkole”, nr 1, s. 22-27; Komunikat Zarządu Głównego Towarzystwa Miłośników Robót Ręcznych $w$ sprawie organizowania kót prowincjonalnych oraz pracowni dla młodzieży i dorosłych, 1927, „Praca Ręczna w Szkole”, nr 2-3, s. 5-9; A. Wójtów, 1928, Międzynarodowy Kongres Rysunkowy w Pradze 1928. „Praca Ręczna w Szkole”, nr 4, s. 37-46; W. Przanowski, 1931, Wystawa w Instytucie Robót Ręcznych. „Praca Ręczna w Szkole”, nr 2-3, s. 4-13; Sprawozdanie z Czwartego Ogólnego Zjazdu Towarzystwa Miłośników Robót Ręcznych, 1935, „Praca Ręczna w Szkole”, nr 2-3, s. 124-128; S. Gabriel, 1935, Wystawa prac uczniów szkół powszechnych. „Praca Ręczna w Szkole”, nr 2-3, s. 181-187; F. Buczkowski, 1936, Polska Wystawa Rysunków i Zajęć Praktycznych na Międzynarodowym Kongresie Ligi Nowego Wychowania. „Praca Ręczna w Szkole”, nr 2-3, s. 118-121; S. Gabriel, 1936, Międzynarodowa Wystawa Rysunków i Robót Ręcznych w Cheltenham (Anglia). „Praca Ręczna w Szkole”, nr 2-3, s. 122-128.

9 Np.: W. Przanowski, 1927, Jakie miejsce zajać powinny roboty ręczne w nauczaniu szkolnym. „Praca Ręczna w Szkole”, nr 1, s. 19-21; W. Przanowski, Najważniejsze postulaty metodyki nauczania robót ręcznych. „Praca Ręczna w Szkole”, nr 1, s. 45-55; I. Huber, 1927, Zaopatrywanie szkoły w najniezbędniejsze pomoce naukowe. „Praca Ręczna w Szkole”, nr 2-3, s. 71-76; W. Przanowski, 1928, Dlaczego i jak należy uczyć robót ręcznych. „Praca Ręczna w Szkole”, nr 1, s. 3-22; W. Czerwiński, 1928, O naukowej organizacji pracy. „Praca Ręczna w Szkole”, nr 2, 52-57; W. Ziółkowski, 1930, Z dyskusji na temat metodyki robót ręcznych, s. 53-58; J. Jodo, 1930, Uwagi o nauczaniu robót ręcznych na wsi. „Praca Ręczna w Szkole”, nr 3-4, s. 32-36; W. Przanowski, 1931, Dlaczego i jak należy uczyć robót ręcznych. Dobre i złe strony różnych rodzajów robót ręcznych. „Praca Ręczna w Szkole”, nr 1, s. 8-14; W. Baran, 1936, Praca ręczna na usługach wychowania. „Praca Ręczna w Szkole", nr 1, s. 39-46; S. Malec, 1936, Jakie korzyści powinno dać uczniom wykonywanie przyrządów w warsztatach szkolnych. „Praca Ręczna w Szkole”, nr 2-3, s. 129-134; L. Rudawski, 1937, 
czasopisma przodował Władysław Przanowski. W periodyku propagowano przekonanie o wychowawczej wartości pracy ręcznej, która obok doskonalenia umiejętności technicznych i manualnych, kształtowała psychikę i osobowość ucznia. O kwestii wpływu pracy ręcznej na rozwój fizyczny, intelektualny i moralny młodzieży pisał między innymi Wacław Radwan ${ }^{10}$. Odrębne artykuły traktowały o slojdzie szwedzkim Otto Salomona, stanowiącym podstawę polskiego systemu nauczania robót ręcznych ${ }^{11}$. Na łamach kwartalnika ukazywały się także konkretne propozycje ćwiczeń oraz wskazówki technologiczne do pracy z określonymi materiałami ${ }^{12}$.

Istotny obszar rozważań podejmowanych w pierwszych numerach „Pracy” stanowiło zagadnienie urządzenia szkolnej pracowni robót ręcznych ${ }^{13}$. W jednym $\mathrm{z}$ artykułów Przanowski - zdając sobie sprawę z lokalowych i materialnych trudności, z jakimi mierzyły się liczne szkoły, zwłaszcza uboższe powszechne szkoły wiejskie - zalecał kierownikom ograniczenie nauczania robót do jednego

Z zagadnień metodyki robót ręcznych. „Praca Ręczna w Szkole”, nr 2-3, s. 217-222; L. Rudawski, 1938, Z zagadnień metodyki robót ręcznych. „Praca Ręczna w Szkole”, nr 1, s. 11-24; M. Wolanin, 1938, Organizacja pracy w nauczaniu zajęć praktycznych. „Praca Ręczna w Szkole”, nr 1, s. 33-36; S. Malec, 1938, Praca ręczna w wychowaniu młodzieży polskiej. „Praca Ręczna w Szkole”, nr 2, s. 112-121.

${ }^{10}$ Np.: W. Radwan, 1927, Znaczenie pracy fizycznej w wychowaniu nowych pokoleń. „Praca Ręczna w Szkole”, nr 1, s, 15-18; K. Noiszewski, 1928, Znaczenie ręki i oka przy nauce zręczności. „Praca Ręczna w Szkole”, nr 2, s. 20-22; C. Bańkowska, 1931, Wpływ nauki rysunków na inteligencję. „Praca Ręczna w Szkole”, nr 2-3, s. 97-102; J. Bogdanowicz, 1935, Zagadnienie zdrowia a praca ręczna w szkole. „Praca Ręczna w Szkole”, nr 1, s. 16-19; W. Sieroszewski, 1935, Praca fizyczna i umysłowa. „Praca Ręczna w Szkole”, nr 2-3, s. 129-131.

${ }^{11}$ Np.: I. Huber, 1930, Slojd pedagogiczny w Szwecji. „Praca Ręczna w Szkole”, nr 1, s. 33-38; G.F. Krog-Clausen, 1930, Szwedzki slojd szkolny. „Praca Ręczna w Szkole”, nr 2, s. 11-18.

${ }^{12}$ Np.: S. Sydorowycz, 1927, Pisanki ukraińskie. Pisanki wczesnohistoryczne. „Praca Ręczna w Szkole”, nr 4, s. 20-48; B. Lenart, 1928, Dzisiejsza „oprawa” i dobra oprawa. „Praca Ręczna w Szkole”, nr 1, s. 23-31; G. Wuttke, 1928, O mapach plastycznych. „Praca Ręczna w Szkole”, nr 1, s. 48-50; K. Bereśniewicz, 1928, Zużywanie materiałów w pracowniach szkolnych. „Praca Ręczna w Szkole”, nr 2, s. 57-59; J. Cierniak, 1928, Szopka ludowa w szkole. „Praca Ręczna w Szkole”, nr 3, s. 29-36; I. Huber, 1928, Przezrocza ręcznie robione. „Praca Ręczna w Szkole”, nr 3, s. 64-69; M. Werten, 1928, Ozdoby choinkowe. „Praca Ręczna w Szkole”, nr 3, s. 37-61; A. Wójtów, 1928, Jakich używać strugnic. „Praca Ręczna w Szkole”, nr 3, s. 22-28; F. Hildebrand, 1930, Barwienie metali. „Praca Ręczna w Szkole”, nr 3-4, s. 103-111; W. Czerwiński, 1930, O niklowaniu i srebrzeniu. „Praca Ręczna w Szkole”, nr 3-4, s. 111-118; B. Czarkowski, 1931, Wiadomości o glinie. „Praca Ręczna w Szkole", nr 1, s. 39-44; W. Czyżycki, 1931, Jak uczyć robót z papieru, kartonu i tektury. Roboty $z$ tektury: tablice, podkładki, teczki, podklejanie map. „Praca Ręczna w Szkole”, nr 2-3, s. 33-56; J. Czarkowska, 1931, Roboty ręczne ze skóry. „Praca Ręczna w Szkole”, nr 2-3, s. 66-76.

${ }^{13}$ Np.: A. Wójtów, 1927, Jak zorganizować nauczanie robót ręcznych $w$ szkołach nie posiadających specjalnej pracowni. „Praca Ręczna w Szkole”, nr 2-3, s. 28-35; W. Przanowski, 1927, Centralne pracownie robót ręcznych przy inspektoratach szkolnych. „Praca Ręczna w Szkole”, nr 2-3, s. 36-40; Z. Andrzejewski, W. Radwan, 1927, Wnętrze pracowni miłośników robót ręcznych. „Praca Ręczna w Szkole”, nr 2-3, s. 41-49; K. Bereśniewicz, 1927, Uwagi o centralnych pracowniach robót ręcznych na zasadzie obserwacji pracowni w Baranowiczach. „Praca Ręczna w Szkole”, nr 4, s. 10-13. 
działu i przystosowanie do niego pomieszczenia, którym dana placówka akurat dysponowała. Natomiast na modelową pracownię robót miały składać się trzy sale: warsztat ręczny, warsztat mechaniczny oraz składzik materiałów, a zarazem muzeum modeli, zebranych i wykonanych przez nauczyciela i uczniów. Sporo miejsca Przanowski poświecił także odpowiedniemu oświetleniu, wentylacji, doborowi narzędzi i materiałów oraz estetyce pracowni: „Jednym z zadań robót ręcznych jest rozwijanie wśród młodzieży kultury estetycznej. Całe urządzenie pracowni musi służyć temu zadaniu przez odpowiednie, gustowne, przyozdabianie ścian ładnymi wyrobami uczniów i miejscowej ludności, wycinkami, ramkami, półeczkami z ceramiką itp. W pracowni stale winna panować wzorowa czystość. [...] Rozbudzając młodzieży wstręt do brudu, a kult dla czystości, dajemy jej jedną z najważniejszych podstaw wychowania, nie tylko estetycznego" ${ }^{14}$.

Związek robót ręcznych z wychowaniem estetycznym i sztuką był omawiany szerzej w artykułach m.in. Niny Bobieńskiej czy Zygmunta Andrzejewskiego ${ }^{15}$. Należy zaznaczyć, że roboty ręczne, a w późniejszym okresie zajęcia praktyczne - obok rysunku i śpiewu - były zaliczane w programach nauczania szkół powszechnych do grupy tzw. przedmiotów artystycznych. W kwartalniku ukazywały się również publikacje dotyczące korelacji rysunku $\mathrm{z}$ robotami ${ }^{16}$ oraz innymi przedmiotami nauczanymi w szkołach, np. przyrodą czy fizykąa ${ }^{17}$.

${ }^{14}$ W. Przanowski, 1927, Urządzenie wzorowej pracowni robót ręcznych w seminariach, szkołach średnich i powszechnych. „Praca Ręczna w Szkole”, nr 2-3, s. 21.

${ }^{15}$ Np.: E. Frankowski, 1928, Sukmany polskie. „Praca Ręczna w Szkole”, nr 2, s. 42-51; W. Szrajberówna, 1928, Uwagi o sztuce ludowej. „Praca Ręczna w Szkole”, nr 2, s. 24-42; D. Bojarunas, 1928, Sztuka czysta i sztuka stosowana. „Praca Ręczna w Szkole”, nr 4, s. 20-25; P.T. Pietrzykowski, 1930, Zabytki sztuki kowalskiej i ślusarskiej na Starym Mieście w Warszawie. „Praca Ręczna w Szkole”, nr 3-4, s. 87-103; N. Bobieńska, 1933, Sztuka romańska w Polsce. „Praca Ręczna w Szkole”, nr 2, s. 91-110; N. Bobieńska, 1936, Wychowanie estetyczne młodzieży. „Praca Ręczna w Szkole”, nr 1, s. 27-31; Z. Andrzejewski, 1937, Wartość sztuki ludowej. „Praca Ręczna w Szkole”, nr 2-3, s. 222-240.

${ }^{16}$ Np.: A. Andrzejewski, 1927, Roboty ręczne jako środek rozwijający poczucie piękna w plastyce. „Praca Ręczna w Szkole”, nr 1, s. 28-39; W. Przanowski, 1927, Nauczyciele rysunków i nauczyciele robót. „Praca Ręczna w Szkole”, nr 4, s, 1-10; W. Czyżycki, 1929, Pomoce naukowe do rysunku. „Praca Ręczna w Szkole”, nr 2, s. 56-61; J. Tor, 1929, O organizację nauki rysunku. „Praca Ręczna w Szkole”, nr 2, s. 45-47; C. Bańkowska, 1931, Rysunek dziecka w świetle psychologii najnowszej. „Praca Ręczna w Szkole”, nr 1, s. 14-20; M. Werten, 1931, O nauce rysunku i robót w szkołach ogólnokształcących wobec nowych zagadnień sztuki i życia. „Praca Ręczna w Szkole”, nr 4, s. 13-27; N. Bobieńska, 1931, Na marginesie książki Karrenberga - Człowiek jako model w szkole powszechnej. „Praca Ręczna w Szkole”, nr 4, s. 73-77; Krysińska-Guzkowa, 1934, Rozwój rysunkowy dziecka $w$ wieku od lat 2 do 5. „Praca Ręczna w Szkole”, nr 3-4, s. 184-188.

${ }_{17}$ Np.: D. Zmigryder-Konopka, 1928, Wspótpraca nauczyciela robót ręcznych z nauczycielem filologii klasycznej. „Praca Ręczna w Szkole”, nr 3, s. 62-64; W. Guzek, S. Malec, 1930, Dział pomocy naukowych. Budowa maszyny elektrostatycznej w pracowni szkolnej. „Praca Ręczna w Szkole”, nr 1, s. 39-52; J. Huber, S. Malec, 1931, Przyrządy do badania ruchów jednostajnie zmiennych (spadkownica, równia pochyła). „Praca Ręczna w Szkole”, nr 1, s. 45-53; B. Salcewiczówna, C. Ścisłowski, 
Osobne, niezbyt nieliczne, teksty podejmowały tematykę nauczania robót kobiecych, będących odmianą robót ręcznych przeznaczoną dla uczennic ${ }^{18}$. Roboty kobiece $\mathrm{w}$ szkole powszechnej obejmowały m.in. szycie i zdobienie, roboty szydełkowe i drutowe oraz łatanie i naprawianie uszkodzonej odzieży.

Kilka interesujących artykułów dotyczyło historii kształcenia w zakresie pracy ręcznej ${ }^{19}$. Opracowania te służyły osadzeniu tego stosunkowo nowego przedmiotu (jakim były roboty ręczne w programach nauczania) w szerszej perspektywie dziejów. Podnosiło to rangę zajęć w oczach nie zawsze przychylnego robotom nauczycielstwa. Inne teksty prezentowały relacje z praktyki szkolnej oraz krytyczne spojrzenia na stan obecny nauczania robót $\mathrm{w} \mathrm{kraju}^{20}$. Warto również podkreślić obecność na łamach kwartalnika tekstów prezentujących doświadczenia autorów zebrane podczas wizyt za granicą, m.in. w Niemczech, Danii, Szwecji, Austrii

1934, Pomoce naukowe z przyrody martwej. „Praca Ręczna w Szkole”, nr 1-2, s. 73-81; J. Markiewicz, P. Kania, 1936, Współpraca nauczyciela zajęć praktycznych z nauczycielem fizyki w kierunku wzbogacenia zbiorów pomocy naukowych. „Praca Ręczna w Szkole”, nr 1, s. 47-58; S. Malec, 1936, Jakie korzyści powinno dać uczniom wykonywanie przyrządów w warsztatach szkolnych. „Praca Ręczna w Szkole”, nr 2-3, s. 129-134; C. Ścisłowski, 1937, Korelacja zajęć praktycznych i fizyki na terenie nowego gimnazjum. „Praca Ręczna w Szkole”, nr 2-3, s. 191-203; I. Huber, 1938, Obróbka szkła. Przykłady pomocy naukowych. „Praca Ręczna w Szkole”, nr 4, s. 240-245.

${ }^{18}$ Np.: M. Dunin-Slugustowska, 1928, O potrzebie nauki robót ręcznych $w$ seminariach dla ochroniarek. „Praca Ręczna w Szkole”, nr 4, s. 25-28; Z. Patkowska, 1929, Uwagi o technikach haftarskich. „Praca Ręczna w Szkole”, nr 2, s. 20-26; H. Bodzińska, 1931, Nasze tkactwo. „Praca Ręczna w Szkole”, nr 2-3, s. 56-66; M. Czechowska, 1933, Kilka uwag o maszynie do szycia. „Praca Ręczna w Szkole”, nr 2, s. 136-145; M. Czechowska, 1934, Ubranie sportowe. „Praca Ręczna w Szkole”, nr 3-4, s. 189-194; M. Rzewuska-Frankowska, 1938, Wartości wychowawcze zajęć praktycznych dla dziewcząt. „Praca Ręczna w Szkole”, nr 2, s. 121-129; M. Vogelsang, 1938, Zajęcia praktyczne dziewcząt a obrona narodowa. „Praca Ręczna w Szkole”, nr 2, s. 130-132.

19 Np.: F. Pększyc, 1927, Krótki zarys rozwoju nauki robót ręcznych w Małopolsce. „Praca Ręczna w Szkole”, nr 2-3, s. 50-58; J. Przyłuski, 1929, Przyczynek do historii nauki robót ręcznych w b. Kongresówce. „Praca Ręczna w Szkole”, nr 2, s. 3-20; M. Dunin-Sulgustowska, 1934, Warunki rozwoju rzemiost w dawnej Polsce. „Praca Ręczna w Szkole”, nr 1-2, s. 22-38; A. Brzezicki, 1936, Praca ręczna w świetle historii wychowania fizycznego. „Praca Ręczna w Szkole”, nr 2-3, s. 140-145; Hildebrand F., 1936, Techniki w robotach ręcznych (historyczny rzut oka wstecz). „Praca Ręczna w Szkole", nr 4, s. 233-237.

${ }^{20}$ Np.: A. Wójtów, 1927, Stan obecny nauczania robót ręcznych w szkołach polskich. „Praca Ręczna w Szkole”, nr 1, s. 40-44; W. Freindorf, 1927, Warsztaty szkolne w Przemyślu. „Praca Ręczna w Szkole", nr 2-3, s. 59-70; K. Bereśniewicz, 1927, Uwagi o centralnych pracowniach robót ręcznych na zasadzie obserwacji pracowni w Baranowiczach. „Praca Ręczna w Szkole”, nr 4, s. 10-13; W. Przanowski, 1930, Nasze bolączki. „Praca Ręczna w Szkole”, nr 3-4, s. 3-8; H. Rzędowski, 1931, Co zrobiono $w$ okręgu szkolnym pomorskim $w$ sprawie podniesienia poziomu nauczania robót ręcznych. „Praca Ręczna w Szkole”, nr 2-3, s. 13-23; W. Przanowski, 1936, Zaopatrywanie powszechnych szkót biedniejszych w pomoce naukowe przez pracownie szkół zamożniejszych. „Praca Ręczna w Szkole”, nr 2-3, s. 146-149; A. Szczepkowski, 1938, Zajęcia praktyczne w okręgu szkolnym krakowskim. „Praca Ręczna w Szkole”, nr 3, s. 195-199; L. Langholz, B. Haan, 1938, Wyniki osiągnięte na lekcjach robót ręcznych w żydowskich szkołach średnich. „Praca Ręczna w Szkole”, nr 4, s. 228-233. 
i Czechosłowacji ${ }^{21}$. W „Pracy Ręcznej w Szkole” pojawiały się także przekłady fragmentów publikacji i wystąpień międzynarodowych autorytetów w dziedzinie rysunków oraz pracy ręcznej ${ }^{22}$.

W kilku ostatnich latach ukazywania się kwartalnika na jego łamach często gościły artykuły przybliżające nowinki techniczne, które stopniowo upowszechniały się w całym społeczeństwie, oraz sposoby ich wykorzystania podczas zajęć $\mathrm{w}$ pracowniach szkolnych ${ }^{23}$. Zbigniew Strzembosz w komentarzu pt. Młode pokolenie a uprzemysłowienie Polski ${ }^{24}$ wskazując na znaczne zapotrzebowanie na rynku pracy na wykwalifikowanych pracowników (m.in. metalowców, betoniarzy, spawaczy, brukarzy), apelował o jak najszybsze rozbudowanie sieci szkół zawodowych i kursów dokształcających. Zajęcia praktyczne postrzegał jako konieczny etap w kształceniu przyszłych specjalistów, na którym formowałyby się dyspozycje niezbędne do przyszłej pracy zawodowej, tj. sprawność rąk, znajomość narzędzi

${ }^{21}$ Np.: W. Przanowski, 1928, Stan nauczania robót ręcznych $w$ Europie. „Praca Ręczna w Szkole”, nr 3, s. 16-21; Huber I., 1928, Stan nauczania robót ręcznych w Niemczech. „Praca Ręczna w Szkole”, nr 4, s. 29-36; Sierotowa J., 1929, Kilka spostrzeżeń ze szkół francuskich. „Praca Ręczna w Szkole”, nr 2, s. 26-33; I. Huber, 1929, Nauczanie robót ręcznych w Danii. „Praca Ręczna w Szkole”, nr 2, s. 33-45; W. Czyżycki, A. Wójtów, 1930, Roboty ręczne w Szwajcarii. „Praca Ręczna w Szkole”, nr 3-4, s. 8-16; N. Bobieńska, 1930, Wrażenia z pobytu w Belgii. „Praca Ręczna w Szkole”, nr 3-4, s. 22-29; M. Rudzińska, 1930, Kilka słów o nauczaniu robót kobiecych w szkołach powszechnych żeńskich w Danii. „Praca Ręczna w Szkole”, nr 3-4, s. 29-32; S. Gabriel, 1931, Roboty ręczne i rysunki w Austrii i Czechosłowacji. „Praca Ręczna w Szkole”, nr 2-3, s. 23-32; M. Werten, 1935, Wychowanie artystyczne w Japonii. „Praca Ręczna w Szkole”, nr 4, s. 264-270; M. Vogelsang, 1936, Stan nauczania robót ręcznych w Szwecji. „Praca Ręczna w Szkole”, nr 2-3, s. 110-117.

${ }^{22}$ Np.: R. Hildebrand, 1930, Nauka robót ręcznych w Polsce i innych krajach. „Praca Ręczna w Szkole”, nr 1, s. 18-24; T. Okanobori, 1931, Popieranie międzynarodowej przyjaźni za pośrednictwem rysunków szkolnych chłopców i dziewcząt. „Praca Ręczna w Szkole”, nr 2-3, s. 91-97.

${ }^{23}$ Np.: S. Malec, 1934, Projektowanie przyrządów elektrycznych. „Praca Ręczna w Szkole”, nr 1-2, s. 66-72; W. Przanowski, 1934, Frontem do techniki. „Praca Ręczna w Szkole”, nr 3-4, s. 137-146; W. Czerwiński, 1934, Zasady działania silników motocyklowych i łódkowych. „Praca Ręczna w Szkole”, nr 3-4, s. 147-162; S. Malec, 1934, Okolicznościowe instalacje świetlne. „Praca Ręczna w Szkole”, nr 3-4, s. 162-166; I. Hubner, 1934, Jak wykonać kuchenkę elektryczną. „Praca Ręczna w Szkole”, nr 3-4, s. 194-198; S. Malec, 1935, Elementy radiotechniki. „Praca Ręczna w Szkole”, nr 1, s. 31-47; W. Czerwiński, 1935, Części składowe i zasady obsługi motocykla. „Praca Ręczna w Szkole”, nr 1, s. 48-68; K. Zacharkiewicz, 1935, Aparat fotograficzny za 5 złotych. „Praca Ręczna w Szkole”, nr 1, s. 82-88; W. Przanowski, 1935, Motoryzacja kraju a szkolnictwo ogólnokształcące. „Praca Ręczna w Szkole”, nr 2-3, s. 132-140; A. Minchejmer, 1936, Techniczne możliwości i potrzeby samodzielnego rozwoju motoryzacji polskiej. „Praca Ręczna w Szkole”, nr 4, s. 237-255; W. Czerwiński, 1937, Człowiek i maszyna. „Praca Ręczna w Szkole”, nr 2-3, s. 184-190; C. Ścisłowski, 1938, Instalacje stosowane w gospodarstwie domowym. „Praca Ręczna w Szkole”, nr 1, s. 36-52; A. Minchejmer, 1938, Na czym polega nowoczesność samochodu? „Praca Ręczna w Szkole”, nr 1, s. 56-81; C. Ścisłowski, 1939, Gaz w gospodarstwie domowym. „Praca Ręczna w Szkole”, nr 1, s. 13-34.

${ }^{24}$ Z. Strzembosz, 1939, Młode pokolenie a uprzemysłowienie Polski. „Praca Ręczna w Szkole”, nr $1, \mathrm{~s}, 3-5$. 
i umiejętność poprawnego władania nimi. W kształceniu na poziomie zawodowym Strzembosz upatrywał rozwiązania problemu bardzo wysokiego poziomu bezrobocia na polskiej wsi. Temat wychowawczej i poniekąd emancypacyjnej roli zajęć praktycznych rozwinął w tym samym numerze kwartalnika Eugeniusz Porębski $\mathrm{w}$ artykule Talent $i$ wytrwałość $w$ zakresie pracy ręcznej ${ }^{25}$. Na szpaltach pisma omawiano także ważką $\mathrm{w}$ drugiej połowie lat 30 . XX wieku tematykę związku zajęć praktycznych z obronnością kraju ${ }^{26}$.

Niekiedy w „Pracy” pojawiały się teksty relacjonujące działalność dydaktyczną Instytutu Robót Ręcznych ${ }^{27}$. Po śmierci Przanowskiego w roku 1937 opublikowano potrójny numer czasopisma, $\mathrm{w}$ całości poświęcony temu zasłużonemu propagatorowi robót. Swoje uznanie dla dorobku redaktora wyrazili wieloletni współpracownicy, wśród nich: Wacław Radwan, Stanisław Dobrowolski i Ignacy Huber ${ }^{28}$.

\section{PODSUMOWANIE}

Ten syntetyczny przegląd tematów podejmowanych na łamach „Pracy Ręcznej w Szkole” w latach 1927-1939 ukazuje przede wszystkim, jak szeroko postrzegano problem powszechnego nauczania robót ręcznych. W kwartalniku omawiano ogólnopedagogiczne znaczenie przedmiotu dla wszechstronnego rozwoju ucznia, przedstawiano rozwiązania metodyczne zarówno w ujęciu teoretycznym, jak i praktycznym oraz wskazywano na ścisły związek przedmiotu z wychowaniem estetycznym, rysunkiem i innymi zajęciami nauczanymi w szkołach. Ponadto przybliżano czytelnikom zagadnienie rozwoju nauczania pracy ręcznej ujęte w perspektywie

${ }^{25}$ E. Porębski, 1939, Talent i wytrwałość w zakresie pracy ręcznej. „Praca Ręczna w Szkole”, nr 1, s. 5-13.

${ }^{26}$ Np.: B. Pikusa, 1935, Surowce a obrona kraju. „Praca Ręczna w Szkole”, nr 1, s. 20-30; M. Vogelsang, 1938, Zajęcia praktyczne dziewcząt a obrona narodowa. „Praca Ręczna w Szkole”, nr 2, s. 130-132; A. Brzezicki, 1938, Przysposobienie wojskowe a zajęcia praktyczne w szkole średniej. „Praca Ręczna w Szkole”, nr 3, s. 174-177; W. Antoszczak, 1938, Jak wykonać ćwiczebna maskę przeciwgazowa. „Praca Ręczna w Szkole”, nr 4, s. 237-240.

${ }^{27}$ Np.: Program studiów w Państwowym Instytucie Robót Ręcznych, 1928, „Praca Ręczna w Szkole”, nr 1, s. 60-68; A. Wójtów, 1928, O kursach wakacyjnych robót ręcznych i rysunków. „Praca Ręczna w Szkole”, nr 1, s. 32-40; W. Przanowski, 1934, Kształcenie i dokształcanie nauczycieli zajęć praktycznych. „Praca Ręczna w Szkole”, nr 3-4, s. 206-216; Komunikat o warunkach przyjmowania kandydatów na I i II kurs Instytutu Robót Ręcznych w roku 1936/7, 1935, „Praca Ręczna w Szkole”, nr 4, s. 287-289.

${ }^{28}$ S. Dobrowolski, 1937, Życiorys śp. Dyrektora Władysława Przanowskiego. „Praca Ręczna w Szkole”, nr 1, s. 5-57; W. Radwan, 1937, Idea, której służył Władysław Przanowski. „Praca Ręczna w Szkole”, nr 1, s. 58-65; I. Huber, 1937, Władysław Przanowski, twórca Państwowego Instytutu Robót Ręcznych. „Praca Ręczna w Szkole”, nr 1, s. 65-79. 
historycznej. Liczne numery zawierały sprawozdania ze zjazdów, wystaw czy konferencji. Kwartalnik prezentował celowo dobrane artykuły wspierające samokształcenie oraz obszerne relacje z pracy w kraju oraz wyjazdów zagranicznych. Stałe grono specjalistów publikujące na szpaltach pisma poruszało szeroki zakres tematów: od naukowej organizacji procesu nauczania poprzez sztukę aż po motoryzację. Teksty zamieszczane w „Pracy Ręcznej w Szkole” stawały się przyczynkiem do dyskusji i refleksji nad organizacją szkolnictwa ogólnokształcącego. I są nimi po dziś dzień.

\section{LITERATURA}

Ambroziewicz W., 1964, Władysław Przanowski i jego dzieło. Warszawa, Państwowe Zakłady Wydawnictw Szkolnych.

Andrzejewski A., 1927, Roboty ręczne jako środek rozwijający poczucie piękna w plastyce. „Praca Ręczna w Szkole”, nr 1, 28-39.

Andrzejewski Z., 1937, Wartość sztuki ludowej. „Praca Ręczna w Szkole”, nr 2-3, 222-240. Andrzejewski Z., Radwan W., 1927, Wnętrze pracowni mitośników robót ręcznych. „Praca Ręczna w Szkole”, nr 2-3, 41-49.

Antoszczak W., 1938, Jak wykonać ćwiczebna maskę przeciwgazowa. „Praca Ręczna w Szkole", nr 4, 237-240.

Bańkowska C., 1931, Rysunek dziecka w świetle psychologii najnowszej. „Praca Ręczna w Szkole", nr 1, 14-20.

Bańkowska C., 1931, Wplyw nauki rysunków na inteligencję. „Praca Ręczna w Szkole”, nr 2-3, 97-102.

Baran W., 1936, Praca ręczna na ustugach wychowania. „Praca Ręczna w Szkole”, nr 1,39-46.

Bereśniewicz K., 1927, Uwagi o centralnych pracowniach robót ręcznych na zasadzie obserwacji pracowni w Baranowiczach. „Praca Ręczna w Szkole”, nr 4, 10-13.

Bereśniewicz K., 1928, Zużywanie materiałów w pracowniach szkolnych. „Praca Ręczna w Szkole", nr 2, 57-59.

Bobieńska N., 1930, Wrażenia z pobytu w Belgii. „Praca Ręczna w Szkole”, nr 3-4, 22-29. Bobieńska N., 1931, Na marginesie książki Karrenberga - Człowiek jako model w szkole powszechnej. „Praca Ręczna w Szkole”, nr 4, 73-77.

Bobieńska N., 1933, Sztuka romańska w Polsce. „Praca Ręczna w Szkole”, nr 2, 91-110. Bobieńska N., 1936, Wychowanie estetyczne młodzieży. „Praca Ręczna w Szkole”, nr 1, 27-31.

Bodzińska H., 1931, Nasze tkactwo. „Praca Ręczna w Szkole”, nr 2-3, 56-66.

Bogdanowicz J., 1935, Zagadnienie zdrowia a praca ręczna w szkole. „Praca Ręczna w Szkole", nr 1, 16-19. 
Bojarunas D., 1928, Sztuka czysta i sztuka stosowana. „Praca Ręczna w Szkole”, nr 4, 20-25.

Brzezicki A., 1936, Praca ręczna $w$ świetle historii wychowania fizycznego. „Praca Ręczna w Szkole”, nr 2-3, 140-145.

Brzezicki A., 1938, Przysposobienie wojskowe a zajęcia praktyczne w szkole średniej. „Praca Ręczna w Szkole”, nr 3, 174-177.

Buczkowski F., 1936, Polska Wystawa Rysunków i Zajęć Praktycznych na Międzynarodowym Kongresie Ligi Nowego Wychowania. „Praca Ręczna w Szkole”, nr 2-3, 118-121.

Cierniak J., 1928, Szopka ludowa w szkole. „Praca Ręczna w Szkole”, nr 3, 29-36.

Czarkowska J., 1931, Roboty ręczne ze skóry. „Praca Ręczna w Szkole”, nr 2-3, 66-76.

Czarkowski B., 1931, Wiadomości o glinie. „Praca Ręczna w Szkole”, nr 1, 39-44.

Czechowska M., 1933, Kilka uwag o maszynie do szycia. „Praca Ręczna w Szkole”, nr 2, 136-145.

Czechowska M., 1934, Ubranie sportowe. „Praca Ręczna w Szkole”, nr 3-4, 189-194.

Czerwiński W., 1928, O naukowej organizacji pracy. „Praca Ręczna w Szkole”, nr 2, 52-57.

Czerwiński W., 1930, O niklowaniu i srebrzeniu. „Praca Ręczna w Szkole”, nr 3-4, 111-118.

Czerwiński W., 1934, Zasady działania silników motocyklowych i łódkowych. „Praca Ręczna w Szkole”, nr 3-4, 147-162.

Czerwiński W., 1935, Części składowe i zasady obsługi motocykla. „Praca Ręczna w Szkole”, nr 1, 48-68.

Czerwiński W., 1937, Człowiek i maszyna. „Praca Ręczna w Szkole”, nr 2-3, 184-190.

Czyżycki W., 1929, Pomoce naukowe do rysunku. „Praca Ręczna w Szkole”, nr 2, 56-61.

Czyżycki W., 1931, Jak uczyć robót z papieru, kartonu i tektury. Roboty z tektury: tablice, podkładki, teczki, podklejanie map. „Praca Ręczna w Szkole”, nr 2-3, 33-56.

Czyżycki W., Wójtów A., 1930, Roboty ręczne w Szwajcarii. „Praca Ręczna w Szkole”, nr 3-4, 8-16.

Dobrowolski S., 1937, Życiorys śp. Dyrektora Władysława Przanowskiego. „Praca Ręczna w Szkole", nr 1, 5-57.

Dunin-Slugustowska M., 1928, O potrzebie nauki robót ręcznych $w$ seminariach dla ochroniarek. „Praca Ręczna w Szkole”, nr 4, 25-28.

Dunin-Sulgustowska M., 1934, Warunki rozwoju rzemiosł $w$ dawnej Polsce. „Praca Ręczna w Szkole”, nr 1-2, 22-38.

Frankowski E., 1928, Sukmany polskie. „Praca Ręczna w Szkole”, nr 2, 42-51.

Freindorf W., 1927, Warsztaty szkolne w Przemyślu. „Praca Ręczna w Szkole”, nr 2-3, 59-70.

Gabriel S., 1931, Roboty ręczne i rysunki w Austrii i Czechosłowacji. „Praca Ręczna w Szkole”, nr 2-3, 23-32. 
Gabriel S., 1935, Wystawa prac uczniów szkół powszechnych. „Praca Ręczna w Szkole”, nr 2-3, 181-187.

Gabriel S., 1936, Międzynarodowa Wystawa Rysunków i Robót Ręcznych w Cheltenham (Anglia). „Praca Ręczna w Szkole”, nr 2-3, 122-128.

Guzek W., Malec S., 1930, Dział pomocy naukowych. Budowa maszyny elektrostatycznej w pracowni szkolnej. „Praca Ręczna w Szkole”, nr 1, 39-52.

Hildebrand F., 1930, Barwienie metali. „Praca Ręczna w Szkole”, nr 3-4, 103-111.

Hildebrand F., 1936, Techniki w robotach ręcznych (historyczny rzut oka wstecz). „Praca Ręczna w Szkole”, nr 4, 233-237.

Hildebrand R., 1930, Nauka robót ręcznych w Polsce i innych krajach. „Praca Ręczna w Szkole”, nr 1, 18-24.

Huber I., 1927, Zaopatrywanie szkoły w najniezbędniejsze pomoce naukowe. „Praca Ręczna w Szkole", nr 2-3, 71-76.

Huber I., 1928, Przezrocza ręcznie robione. „Praca Ręczna w Szkole”, nr 3, 64-69.

Huber I., 1928, Stan nauczania robót ręcznych w Niemczech. „Praca Ręczna w Szkole”, nr 4, 29-36.

Huber I., 1929, Nauczanie robót ręcznych w Danii. „Praca Ręczna w Szkole”, nr 2, 33-45. Huber I., 1930, Slojd pedagogiczny w Szwecji. „Praca Ręczna w Szkole”, nr 1, 33-38.

Huber I., 1934, Jak wykonać kuchenkę elektryczną. „Praca Ręczna w Szkole”, nr 3-4, 194-198.

Huber I., 1937, Władysław Przanowski, twórca Państwowego Instytutu Robót Ręcznych. „Praca Ręczna w Szkole”, nr 1, 65-79.

Huber I., 1938, Obróbka szkła. Przykłady pomocy naukowych. „Praca Ręczna w Szkole", nr 4, 240-245.

Huber J., Malec S., 1931, Przyrządy do badania ruchów jednostajnie zmiennych (spadkownica, równia pochyła). „Praca Ręczna w Szkole”, nr 1, 45-53.

Jodo J., 1930, Uwagi o nauczaniu robót ręcznych na wsi. „Praca Ręczna w Szkole”, nr 3-4, 32-36.

Komunikat o warunkach przyjmowania kandydatów na I i II kurs Instytutu Robót Ręcznych w roku 1936/7, 1935. „Praca Ręczna w Szkole”, nr 4, 287-289.

Komunikat Zarządu Głównego Towarzystwa Miłośników Robót Ręcznych w sprawie organizowania kół prowincjonalnych oraz pracowni dla młodzieży $i$ dorosłych, 1927. „Praca Ręczna w Szkole”, nr 2-3, 5-9.

Krog-Clausen G.F., 1930, Szwedzki slojd szkolny. „Praca Ręczna w Szkole”, nr 2, 11-18. Krysińska-Guzkowa, 1934, Rozwój rysunkowy dziecka w wieku od lat 2 do 5. „Praca Ręczna w Szkole”, nr 3-4, 184-188.

Langholz L., Haan B., 1938, Wyniki osiagnięte na lekcjach robót ręcznych w żydowskich szkołach średnich. „Praca Ręczna w Szkole”, nr 4, 228-233.

Lenart B., 1928, Dzisiejsza „oprawa” i dobra oprawa. „Praca Ręczna w Szkole”, nr 1, 23-31. 
Malec S., 1934, Okolicznościowe instalacje świetlne. „Praca Ręczna w Szkole”, nr 3-4, 162-166.

Malec S., 1934, Projektowanie przyrządów elektrycznych. „Praca Ręczna w Szkole”, nr 1-2, 66-72.

Malec S., 1935, Elementy radiotechniki. „Praca Ręczna w Szkole”, nr 1, 31-47.

Malec S., 1936, Jakie korzyści powinno dać uczniom wykonywanie przyrządów w warsztatach szkolnych. „Praca Ręczna w Szkole”, nr 2-3, 129-134.

Malec S., 1938, Praca ręczna w wychowaniu młodzieży polskiej. „Praca Ręczna w Szkole", nr 2, 112-121.

Markiewicz J., Kania P., 1936, Współpraca nauczyciela zajęć praktycznych z nauczycielem fizyki w kierunku wzbogacenia zbiorów pomocy naukowych. „Praca Ręczna w Szkole", nr 1, 47-58.

Minchejmer A., 1936, Techniczne możliwości i potrzeby samodzielnego rozwoju motoryzacji polskiej. „Praca Ręczna w Szkole”, nr 4, 237-255.

Minchejmer A., 1938, Na czym polega nowoczesność samochodu?. „Praca Ręczna w Szkole”, nr 1, 56-81.

Możdżeń S., Musiał J., 1981, Bibliografia polskich czasopism pedagogicznych (do 1979 r.). Kielce, Wydawnictwo Wyższej Szkoły Pedagogicznej im. Jana Kochanowskiego.

Noiszewski K., 1928, Znaczenie ręki i oka przy nauce zręczności. „Praca Ręczna w Szkole”, nr 2, 20-22

Okanobori T., 1931, Popieranie międzynarodowej przyjaźni za pośrednictwem rysunków szkolnych chłopców i dziewcząt. „Praca Ręczna w Szkole”, nr 2-3, 91-97.

Patkowska Z., 1929, Uwagi o technikach haftarskich. „Praca Ręczna w Szkole”, nr 2, 20-26.

Pększyc F., 1927, Krótki zarys rozwoju nauki robót ręcznych w Małopolsce. „Praca Ręczna w Szkole”, nr 2-3, 50-58.

Pietrzykowski P.T., 1930, Zabytki sztuki kowalskiej i ślusarskiej na Starym Mieście w Warszawie. „Praca Ręczna w Szkole”, nr 3-4, 87-103.

Pikusa B., 1935, Surowce a obrona kraju. „Praca Ręczna w Szkole”, nr 1, 20-30.

Porębski E., 1939, Talent $i$ wytrwałość w zakresie pracy ręcznej. „Praca Ręczna w Szkole”, nr 1, 5-13.

Program studiów w Państwowym Instytucie Robót Ręcznych, 1928, „Praca Ręczna w Szkole", nr 1, 60-68.

Przanowski W., 1927, Centralne pracownie robót ręcznych przy inspektoratach szkolnych. „Praca Ręczna w Szkole”, nr 2-3, 36-40.

Przanowski W., 1927, Jakie miejsce zająć powinny roboty ręczne w nauczaniu szkolnym. „Praca Ręczna w Szkole”, nr 1, 19-21.

Przanowski W., 1927, Nauczyciele rysunków i nauczyciele robót. „Praca Ręczna w Szkole”, nr 4, 1-10. 
Przanowski W., 1927, Urządzenie wzorowej pracowni robót ręcznych w seminariach, szkołach średnich i powszechnych. „Praca Ręczna w Szkole”, nr 2-3.

Przanowski W., 1928, Dlaczego i jak należy uczyć robót ręcznych. „Praca Ręczna w Szkole", nr 1, 3-22.

Przanowski W., 1928, Stan nauczania robót ręcznych w Europie. „Praca Ręczna w Szkole", nr 3, 16-21.

Przanowski W., 1930, Nasze bolączki. „Praca Ręczna w Szkole”, nr 3-4, 3-8.

Przanowski W., 1931, Dlaczego i jak należy uczyć robót ręcznych. Dobre i złe strony różnych rodzajów robót ręcznych. „Praca Ręczna w Szkole”, nr 1, 8-14.

Przanowski W., 1931, Wystawa w Instytucie Robót Ręcznych. „Praca Ręczna w Szkole”, nr 2-3, 4-13.

Przanowski W., 1934, Frontem do techniki. „Praca Ręczna w Szkole”, nr 3-4, 137-146. Przanowski W., 1934, Kształcenie i dokształcanie nauczycieli zajęć praktycznych. „Praca Ręczna w Szkole”, nr 3-4, 206-216.

Przanowski W., 1935, Motoryzacja kraju a szkolnictwo ogólnokształcące. „Praca Ręczna w Szkole", nr 2-3, 132-140.

Przanowski W., 1936, Zaopatrywanie powszechnych szkół biedniejszych w pomoce naukowe przez pracownie szkół zamożniejszych. „Praca Ręczna w Szkole”, nr 2-3, 146-149.

Przanowski W., Najważniejsze postulaty metodyki nauczania robót ręcznych. „Praca Ręczna w Szkole”, nr 1, 45-55.

Przyłuski J., 1929, Przyczynek do historii nauki robót ręcznych w b. Kongresówce. „Praca Ręczna w Szkole", nr 2, 3-20.

Radwan W., 1927, Znaczenie pracy fizycznej w wychowaniu nowych pokoleń. „Praca Ręczna w Szkole”, nr 1, 15-18.

Radwan W., 1937, Idea, której służył Władysław Przanowski. „Praca Ręczna w Szkole”, nr $1,58-65$.

Rudawski L., 1937, Z zagadnień metodyki robót ręcznych. „Praca Ręczna w Szkole”, nr 2-3, 217-222.

Rudawski L., 1938, Z zagadnień metodyki robót ręcznych. „Praca Ręczna w Szkole”, nr 1, 11-24.

Rudzińska M., 1930, Kilka słów o nauczaniu robót kobiecych w szkołach powszechnych żeńskich w Danii. „Praca Ręczna w Szkole”, nr 3-4, 29-32.

Rzewuska-Frankowska M., 1938, Wartości wychowawcze zajęć praktycznych dla dziewcząt. „Praca Ręczna w Szkole”, nr 2, 121-129.

Rzędowski H., 1931, Co zrobiono w okręgu szkolnym pomorskim w sprawie podniesienia poziomu nauczania robót ręcznych. „Praca Ręczna w Szkole”, nr 2-3, 13-23.

Salcewiczówna B., Ścisłowski C., 1934, Pomoce naukowe z przyrody martwej. „Praca Ręczna w Szkole”, nr 1-2, 73-81. 
Sieroszewski W., 1935, Praca fizyczna i umysłowa. „Praca Ręczna w Szkole”, nr 2-3, $129-131$.

Sierotowa J., 1929, Kilka spostrzeżeń ze szkół francuskich. „Praca Ręczna w Szkole”, nr 2, 26-33.

Sprawozdanie z Czwartego Ogólnego Zjazdu Towarzystwa Miłośników Robót Ręcznych, 1935. „Praca Ręczna w Szkole”, nr 2-3, 124-128.

Sprawozdanie z Pierwszego Polskiego Zjazdu nauczycieli robót ręcznych $w$ Warszawie, 1927. „Praca Ręczna w Szkole”, nr 1, 11-14.

Sprawozdanie z wystaw szkolnych, 1927. „Praca Ręczna w Szkole”, nr 1, 22-27.

Strzembosz Z., 1939, Młode pokolenie a uprzemysłowienie Polski. „Praca Ręczna w Szkole”, nr 1, 3-5.

Sydorowycz S., 1927, Pisanki ukraińskie. Pisanki wczesnohistoryczne. „Praca Ręczna w Szkole", nr 4, 20-48.

Szczepkowski A., 1938, Zajęcia praktyczne w okregu szkolnym krakowskim. „Praca Ręczna w Szkole", nr 3, 195-199.

Szrajberówna W., 1928, Uwagi o sztuce ludowej. „Praca Ręczna w Szkole”, nr 2, 24-42.

Ścisłowski C., 1937, Korelacja zajęć praktycznych i fizyki na terenie nowego gimnazjum. „Praca Ręczna w Szkole”, nr 2-3, 191-203.

Ścisłowski C., 1938, Instalacje stosowane w gospodarstwie domowym. „Praca Ręczna w Szkole", nr 1, 36-52.

Ścisłowski C., 1939, Gaz w gospodarstwie domowym. „Praca Ręczna w Szkole”, nr 1, 13-34. Tor J., 1929, O organizację nauki rysunku. „Praca Ręczna w Szkole”, nr 2, 45-47.

Vogelsang M., 1936, Stan nauczania robót ręcznych $w$ Szwecji. „Praca Ręczna w Szkole", nr 2-3, 110-117.

Vogelsang M., 1938, Zajęcia praktyczne dziewcząt a obrona narodowa. „Praca Ręczna w Szkole”, nr 2, 130-132.

Werten M., 1928, Ozdoby choinkowe. „Praca Ręczna w Szkole”, nr 3, 37-61.

Werten M., 1931, O nauce rysunku i robót w szkołach ogólnokształcacych wobec nowych zagadnień sztuki i życia. „Praca Ręczna w Szkole”, nr 4, 13-27.

Werten M., 1935, Wychowanie artystyczne w Japonii. „Praca Ręczna w Szkole”, nr 4, 264-270.

Wolanin M., 1938, Organizacja pracy w nauczaniu zajęć praktycznych. „Praca Ręczna w Szkole", nr 1, 33-36.

Wójtów A., 1927, Jak zorganizować nauczanie robót ręcznych w szkołach nie posiadajacych specjalnej pracowni. „Praca Ręczna w Szkole”, nr 2-3, 28-35.

Wójtów A., 1927, Stan obecny nauczania robót ręcznych w szkołach polskich. „Praca Ręczna w Szkole”, nr 1, 40-44.

Wójtów A., 1928, Jakich używać strugnic. „Praca Ręczna w Szkole”, nr 3, 22-28.

Wójtów A., 1928, Międzynarodowy Kongres Rysunkowy w Pradze 1928. „Praca Ręczna w Szkole", nr 4, 37-46. 
Wójtów A., 1928, O kursach wakacyjnych robót ręcznych i rysunków. „Praca Ręczna w Szkole", nr 1, 32-40.

Wuttke G., 1928, O mapach plastycznych. „Praca Ręczna w Szkole”, nr 1, 48-50.

Zacharkiewicz K., 1935, Aparat fotograficzny za 5 złotych. „Praca Ręczna w Szkole”, nr $1,82-88$.

Ziółkowski W., 1930, Z dyskusji na temat metodyki robót ręcznych. 53-58.

Zmigryder-Konopka D., 1928, Współpraca nauczyciela robót ręcznych z nauczycielem filologii klasycznej. „Praca Ręczna w Szkole”, nr 3, 62-64.

\title{
PROBLEMS OF UNIVERSAL MANUAL WORK EDUCATION IN QUARTERLY „MANUAL WORK IN SCHOOL” (1927-1939)
}

\begin{abstract}
In the interwar years, the Polish pedagogical press experienced intense development. Numerous periodicals devoted to the issues of general, secondary and vocational education, periodicals about non-school education and methodical and subject writings were published. One of the recognized methodological writings was „Manual Work at School” (1927-1939). In the quarterly was discussed the broadly understood problem of teaching manual works in general schools: the issue of the impact of manual work on student development, methodological solutions were presented both in theoretical and practical terms, and the relationship between the subject and aesthetic education and other classes taught at schools was pointed out. Numerous numbers contained reports on conventions, exhibitions and conferences taking place in Poland and abroad. The quarterly presented deliberately selected articles supporting teachers' self-education. A permanent group of specialists in their articles addressed a wide range of topics: from the scientific organization of the teaching process through art to the automotive industry. Texts posted in „Manual Work at School” became a contribution to the discussion and reflection on the organization of education.
\end{abstract}

Keywords: general education, manual work, Polish magazines, XX century 